\title{
The Causes of Progressive Stagnation
}

\author{
SAIKRISHNA PRAKASH*
}

In recent decades, the most elite stratum of progressive academic opinion has soured on the courts as an engine of constitutional change. Books written by the stars of the progressive firmament have rejected the traditional reliance on the courts as engines of legal change. ${ }^{1}$ Other liberals have bemoaned the judiciary's ability to propel social change. Gerald Rosenberg argued this over two decades ago, ${ }^{2}$ with Michael Klarman making a related argument more recently. ${ }^{3}$

The vanguard has led, but has the rearguard followed? Judging from the scholarship in law reviews and the remarks at our Symposium on progressive constitutional law, the anecdotal answer is "no." Among the progressive professoriate, the appeal of judicial minimalism has been minimal. Moreover, that professoriate has not sought to wrest the Constitution away from the courts.

What accounts for the disconnect between the high end of elite progressive opinion and its other stratums? Why hasn't there been a greater rejection of judicial review, or a more sustained and broad effort to discredit the courts? To be sure, there have been (and will continue to be) efforts to discredit particular opinions. For instance, many progressives denounced Citizens United v. FEC, ${ }^{4}$ with one doing so at the State of the Union. ${ }^{5}$ Yet there has been no persistent, general campaign to tear down the courts.

Simple reasons account for the failure of the vanguard to convince the rearguard to humble the courts. Habit, identification, preference satisfaction, and the fact that courts remain the most meaningful constitutional game in town all contribute to the continued progressive preference for the courts as the locus of constitutional decision making.

First, habit. Most liberals are accustomed to regarding the courts as an engine of progressive change. To be sure, there have been notorious pockets of

* David Lurton Massee, Jr. and Sullivan \& Cromwell Professor of Law, University of Virginia. Thanks to John Harrison and Steve Walt for helpful discussions and Archith Ramkumar for comments and research support.

${ }^{1}$ See, e.g., LARRY KRAMER, The PEOPle ThemSelves: PoPular Constitutionalism AND JUdicial REVIEW 249-53 (2004); CASS SUNSTEIN, RadiCALS IN RoBES, at xiv-xv, 6-7, 12-19 (2005); MARK TUSHNET, TAKING THE CONSTITUTION AWAY FROM THE COURTS 154$77(2000)$.

2 See Gerald Rosenberg, The Hollow Hope: Can Courts Bring About Social ChANGE? (1991).

${ }^{3}$ Michael Klarman, From Jim Crow to Civil Rights: The Supreme CoUrt and THE StRUGGLE FOR RACIAL EQUALITY 22-27, 29-34, 37-47 (2004).

${ }^{4} 130$ S. Ct. 876 (2010).

${ }^{5}$ President Barack H. Obama, State of the Union Address (Jan. 27, 2010), in 156 CONG. REC. H418 (daily ed. Jan. 27, 2010) ("With all due deference to separation of powers, last week the Supreme Court reversed a century of law that I believe will open the floodgates for special interests-including foreign corporations-to spend without limit in our elections."). 
constitutional darkness, like Dred Scott v. Sandford ${ }^{6}$ Plessy v. Ferguson, ${ }^{7}$ and Lochner $v$. New York. ${ }^{8}$ But for the most part, the courts have been the heroes of the progressive constitutional fable, expanding individual rights and the scope of federal power. In this tale, Justices like Earl Warren, William Brennan, and Thurgood Marshall are the most recent exemplars of the heroic judge, with the Great Chief Justice serving as an early apostle of sweeping federal power of the sort championed by progressives in the twentieth century. Because old habits die hard, progressives are unlikely to be moved by a few years (even decades) of mixed results in the courts and a smattering of books highly critical of the courts.

If I am right, one might expect a generational shift between younger progressives and older ones. The young pups can be taught new tricks because they lack the sentimental and familiar attachment to the courts. They have not seen or experienced a time where the courts consistently favored a progressive agenda on criminal or civil rights. In contrast, older progressives are more likely to be unreconstructed judicial supremacists, ever ready to criticize particular decisions and to bemoan a general direction, but unable to overcome their longheld reverence for the courts. A similar split may have characterized the progressive movement in the 1950s and 1960s, as the admirers of Brandeis, Holmes, and Frankfurter-those who believed in judicial restraint-gradually gave way to those who admired the activists, like Brennan.

Another reason why progressives cannot abandon the courts lies in the ready identification of legal academics with the judiciary, and in particular, the Supreme Court. Both academics and judges wear robes, when the occasion calls for it. Both academics and judges have a scholarly bent, believing in the value of reflection and the need to carefully digest arguments and claims. Both pen long and discursive writings, full of citations to authority. Moreover, legal scholars typically focus on judicial decision making in their courses and in their scholarship as well, a tendency that perhaps leads them to the conclusion that the Constitution's fate properly rests in the hands of judges. Indeed, in many courses, the Supreme Court and its opinions are a central aspect of the discussions. Finally, one cannot discount the fact that many academics have apprenticed with a judge or Justice. Such experiences may not only elevate the particular judge in the minds of the clerk-turned-academic, but also the entire bench. Again, this identification does not prevent scholars from criticizing particular decisions. But it does perhaps make many scholars less inclined to adopt a stance of unremitting hostility toward the courts, especially while their former employer and/or hero remains on the bench.

Third, there is the practical, comparative question. Which of the four institutions-Congress, the Presidency, the states, or the courts-seems most progressive? For many the answer must seem obvious. I would venture to say

\footnotetext{
660 U.S. (19 How.) 393 (1857)

${ }^{7} 163$ U.S. 537 (1896).

8198 U.S. 45 (1905).
} 
that in the recent past, the courts have clearly been the most progressive of these institutions. Another way to put this is that the median Harvard, NYU, or Minnesota law professor is much more likely to prefer the median Supreme Court Justice than the median member of Congress. Hence, the courts do not have to be completely liberal, much less always favor progressive outcomes. They just need to generate better outcomes than the alternatives.

For progressives, judicial output is superior in two other, related senses. To begin with, maintaining judicial review as it is preserves some liberal sacred cows. As much as progressives may not like Citizens United and the like, many do not want a new regime of a muscular Congress or President, one less likely to preserve liberal totems like Wickard v. Filburn, ${ }^{9}$ Roe v. Wade, ${ }^{10}$ and Lemon v. Kurtzman. ${ }^{11}$ Liberals most interested in criminal procedure, free speech, or sexual liberty have much to preserve, and thus have much to fear about a regime where the judiciary is knocked off from its lofty constitutional perch.

Moreover, the ongoing benefits that liberals derive should not be disregarded. Recent cases like Lawrence v. Texas, ${ }^{12}$ Hamdan v. Rumsfeld, ${ }^{13}$ and Boumediene v. Bush ${ }^{14}$ make it clear that liberals occasionally win what they perceive as big victories. I do not believe that the Supreme Court majorities in these cases were trying to retain liberal support for the judiciary. But there is no doubt that occasional progressive victories keep at least some liberals invested in defending the courts.

Fourth, the Supreme Court remains the most important venue for constitutional decision making. This is not to say that Congress does not consider the Constitution as it legislates, and it is not to deny that the President sometimes advances his own constitutional vision. But only the Court has a jurisdiction that regularly extends to both federal and state action, from whatever branch, meaning that it will see many more constitutional cases than any other institution. In other words, the judiciary, especially the Supreme Court, is the principal venue for constitutional skirmishes. Most liberals are sensible enough not to abandon the field merely because a few skirmishes have not gone their way. In an era where conservative and libertarian public interest groups are mimicking the strategies and tactics of their liberal counterparts, liberals cannot afford to beat a full retreat.

None of this denies that many progressives have the long-term goal of tearing down the courts. The claims of Tushnet, Sunstein, or Kramer may have convinced some, or even many, progressives. But even so, many progressives must realize, like John Maynard Keynes, that in the long term we are all dead. ${ }^{15}$ And they also have to realize that any attempt to weaken the courts may fail.

\footnotetext{
9317 U.S. 111 (1942).

10410 U.S. 113 (1973).

11403 U.S. 602 (1971).

12539 U.S. $558(2003)$.

13548 U.S. 557 (2006).

14553 U.S. 723 (2008).

15 JOHN MAYNARD KEYNES, MONETARY REFORM 88 (1924).
} 
Knowing this, many progressives understand that what matters is what is happening now and right now, the courts are the best constitutional game in town.

Will the causes of progressive stagnation ever disappear or dissipate? Things can change over longer periods of time, as new ideas are introduced and they take hold in the broader populace. And it may well be that the Tushnets, Kramers, and Sunsteins are catalysts, helping further that process along. All that I can say with (relative) certainty is that so long as the courts are the best forum for progressives, on many dimensions, they will not be quick to abandon it. 